\title{
Analysis of the local position of electric vehicle frame connection by steel and aluminum hybrid material
}

\author{
Zhuo Yang $^{1, a}$, Gongrui Sun ${ }^{\star 1, b}$, Shaojia Huang ${ }^{1, c}$, Baoqing Deng ${ }^{1, d}$ \\ ${ }^{1}$ Department of Mechanical and Automotive Engineering, Zhuhai College of Jilin University, Zhuhai, \\ China \\ a641610495@qq.com, b81736476@qq.com, cJafield@yeah.net, d843723111@qq.com
}

Keywords: Frame connection; Steel and aluminum hybrid material; Optimization

\begin{abstract}
With the advantages of low energy consumption and zero emissions, pure electric vehicles are tent to be the substitution of the traditional vehicles. However, there are a lot of electric frames still made of welded square steel and angle iron, it can increase the intensity of the frame by this way, and the total weight of the vehicle will be increased and then waste the limited energy of the vehicle batteries. So in this research, the lightweight material aluminum alloy is used to be combined with square steel as the new vehicle frame. And such two different kinds of materials were combined using riveting way. Two types of structure, $40 \times 40 \times 3$ and $30 \times 30 \times 3$, were used in this research. In order to validate the results, the analyze function of the Ansys Workbench 14.5 can be used to analyze the overall frame to determine the optimal stress distribution and deformation conditions.
\end{abstract}

\section{Riveting design}

There are two kinds of riveting way for the combining of the square steel and the angle iron. For the first one, as shown in the figure $1(\mathrm{a})$, the size $40 \times 40 \times 3$ material was used as the frame and another material was inserted it. Another one is the $30 \times 30 \times 3$ as the former, and then it was riveted on another material, as shown in figure 1(b).
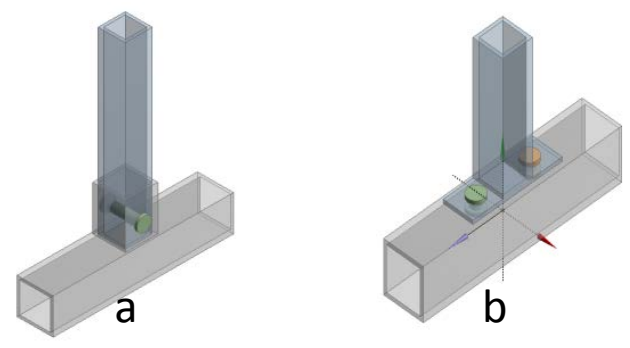

Figure1.Riveting design

When interchange the different size and materials, we can get such compositions as shown in Table 1. 
Table 1 Riveting method

\begin{tabular}{|c|c|c|c|c|}
\hline No. & $\begin{array}{c}\text { Riveting } \\
\text { design }\end{array}$ & \multicolumn{2}{|c|}{ Riveting method } & Schematic diagram \\
\hline & \multirow{2}{*}{$\begin{array}{c}\text { Frame } \\
\text { riveting }\end{array}$} & $(1)$ & Structural steel interest into Aluminum alloy welding & \\
\cline { 3 - 6 } & $(2)$ & Aluminum alloy interest into structural steel welding & \\
\hline b & $\begin{array}{c}\text { Spoke } \\
\text { riveting }\end{array}$ & $(3)$ & Structural steel former and Aluminum alloy welding & \\
\cline { 3 - 6 } & & $(4)$ & Aluminum alloy former and structural steel welding & \\
\hline
\end{tabular}

\section{Simulation analysis}

In this paper, the Geometry module of the ANSYS Workbench is used to create the 3D model, and then analysis the static loading by the Static Structural module. And the parts of the mount support in the front suspension is the analysis model which bear the weight of batteries $(135 \mathrm{~kg})$ and the driver (65kg), as shown in the Figure 2.

Specific programs loaded as shown in Figure 3. Optimal design consideration is pulled $2000 \mathrm{~N}$ in the case, for other loading can also be treated in the same way, this article does not repeat all.

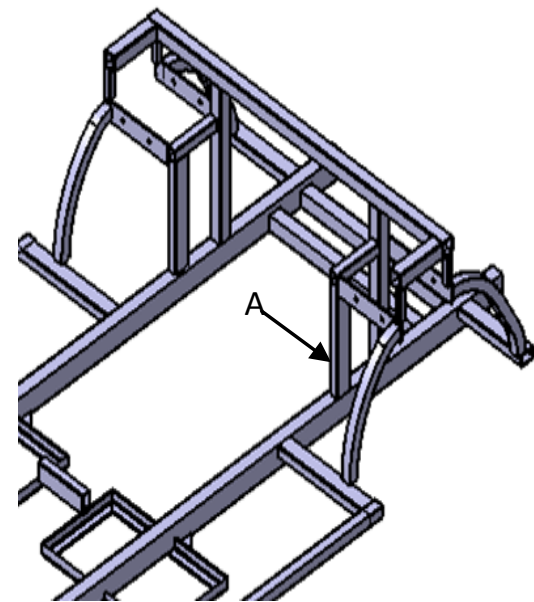

Figure2.Diagram of Analysis

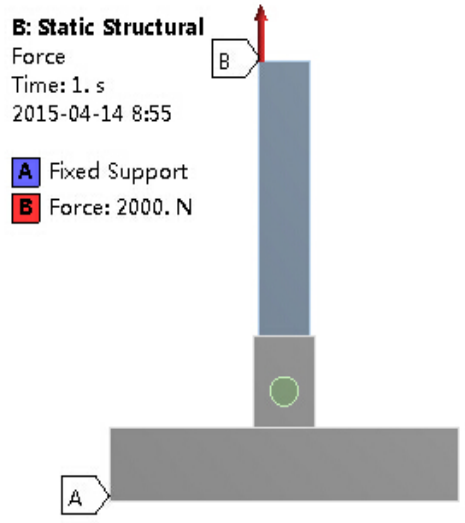

Load of Riveting design a

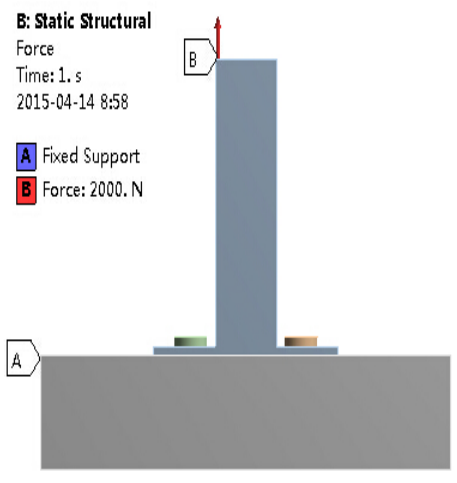

Load of Riveting design $b$

Figure3.Load program

\section{Parameters and Optimization}

\section{Optimal parameters}

Parameterization modeling is used to select the diameter of the rivet hole and the distance between the center of the rivet hole and the edge, as shown in the figure 4 .

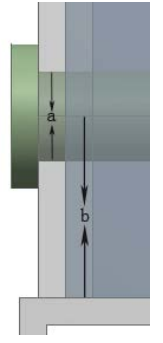

Optimal parameter of Riveting design a

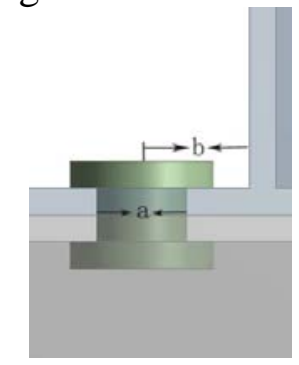

Optimal parameters of Riveting design b

Figure 4. Optimal parameters 


\section{Target parameters}

The target parameters are the maximum distortion value and the maximum stress value.

\section{Analyze process and results}

The analyze process is operated in ANSYS Workbench. The four connections are applied to optimize the analysis, the response surfaces are shown in Table 2, and each connection and the minimum amount of deformation data are selected. System minimum stress values for optimal results are shown in Table 3.

Table 2 Response Surface

\begin{tabular}{|c|c|c|}
\hline Response surface type & Riveting method & response surface \\
\hline \multirow{4}{*}{$\begin{array}{l}\text { Numerical optimization } \\
\text { parameters on the deformation } \\
\text { response surface }\end{array}$} & $\begin{array}{l}\text { Structural steel interest into Aluminum } \\
\text { alloy welding }\end{array}$ & \\
\hline & $\begin{array}{l}\text { Aluminum alloy interest into structural steel } \\
\text { welding }\end{array}$ & : \\
\hline & $\begin{array}{l}\text { Structural steel former and Aluminum alloy } \\
\text { welding }\end{array}$ & \\
\hline & $\begin{array}{l}\text { Aluminum alloy former and structural steel } \\
\text { welding }\end{array}$ & 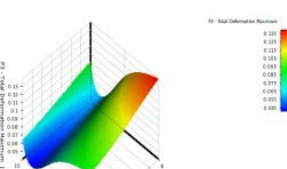 \\
\hline \multirow{4}{*}{$\begin{array}{l}\text { Numerical optimization } \\
\text { parameters on the stress response } \\
\text { surface }\end{array}$} & $\begin{array}{l}\text { Structural steel interest into Aluminum } \\
\text { alloy welding }\end{array}$ & \\
\hline & $\begin{array}{c}\text { Aluminum alloy interest into structural steel } \\
\text { welding }\end{array}$ & \\
\hline & $\begin{array}{l}\text { Structural steel former and Aluminum alloy } \\
\text { welding }\end{array}$ & \\
\hline & $\begin{array}{c}\text { Aluminum alloy former and structural steel } \\
\text { welding }\end{array}$ & \\
\hline
\end{tabular}


Table3 Total Deformation Maximum Minimum and Equivalent Stress Maximum Minimum

\begin{tabular}{|c|c|c|c|c|c|}
\hline $\begin{array}{l}\text { Riveting } \\
\text { method }\end{array}$ & Design Point & $\begin{array}{c}\text { Total } \\
\text { Deformation } \\
/ \mathrm{mm} \\
\end{array}$ & $\begin{array}{l}\text { Equivalent } \\
\text { Stress } \\
\text { /Mpa }\end{array}$ & $\begin{array}{c}\text { Rivet hole } \\
\text { diameter } \\
/ \mathrm{mm}\end{array}$ & $\begin{array}{l}\text { Distance from hole } \\
\text { center to the edge } \\
\text { /mm }\end{array}$ \\
\hline \multirow{2}{*}{$\begin{array}{l}\text { Structural steel } \\
\text { interest into } \\
\text { Aluminum } \\
\text { alloy riveting }\end{array}$} & $\begin{array}{l}\text { Total Deformation } \\
\text { Maximum Minimum } \\
\text { Design Point }\end{array}$ & 0.043561 & 46.781 & 15 & 15 \\
\hline & $\begin{array}{c}\text { Equivalent Stress } \\
\text { Maximum Minimum } \\
\text { Design Point }\end{array}$ & 0.043777 & 46.649 & 15 & 22.784 \\
\hline \multirow{2}{*}{$\begin{array}{c}\text { Aluminum } \\
\text { alloy interest } \\
\text { into structural } \\
\text { steel riveting }\end{array}$} & $\begin{array}{l}\text { Total Deformation } \\
\text { Maximum Minimum } \\
\text { Design Point }\end{array}$ & 0.034654 & 44.231 & 15 & 22.784 \\
\hline & $\begin{array}{c}\text { Equivalent Stress } \\
\text { Maximum Minimum } \\
\text { Design Point }\end{array}$ & 0.034393 & 44.231 & 15 & 25 \\
\hline \multirow{2}{*}{$\begin{array}{l}\text { Structural steel } \\
\text { former and } \\
\text { Aluminum } \\
\text { alloy riveting }\end{array}$} & $\begin{array}{l}\text { Total Deformation } \\
\text { Maximum Minimum } \\
\text { Design Point }\end{array}$ & 0.038439 & 67.609 & 15 & 11.374 \\
\hline & $\begin{array}{c}\text { Equivalent Stress } \\
\text { Maximum Minimum } \\
\text { Design Point }\end{array}$ & 0.042252 & 167.37 & 13.773 & 11.486 \\
\hline \multirow{2}{*}{$\begin{array}{c}\text { Aluminum } \\
\text { alloy former } \\
\text { and structural } \\
\text { steel riveting }\end{array}$} & $\begin{array}{c}\text { Total Deformation } \\
\text { Maximum Minimum } \\
\text { Design Point } \\
\end{array}$ & 0.03916 & 65.312 & 15 & 10 \\
\hline & $\begin{array}{l}\text { Equivalent Stress } \\
\text { Maximum Minimum } \\
\text { Design Point }\end{array}$ & 0.03916 & 65.312 & 15 & 10 \\
\hline
\end{tabular}

In summary, the optimal plan is that Aluminum alloy interest into structural steel welding plan when the diameter of the rivet hole is $15 \mathrm{~mm}$, and the distance between the center of the rivet hole and the edge is $25 \mathrm{~mm}$.

\section{Conclusion}

According to the analyzing, the deformation deprogram、stress deprogram、strain deprogram are show in the Figure 5.

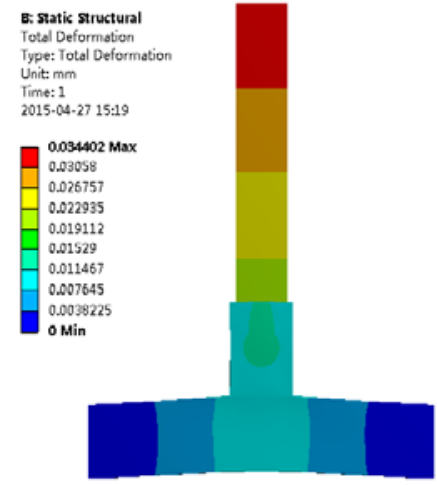

The deformation nephogram

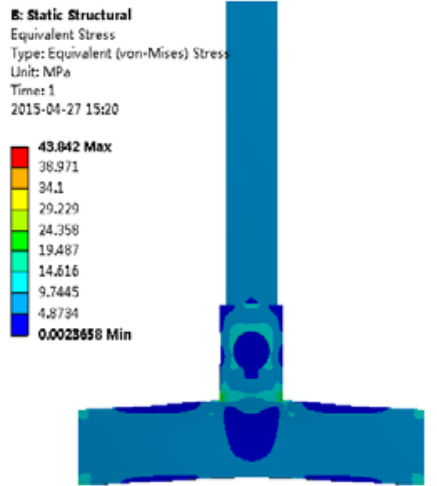

Stress nephogram

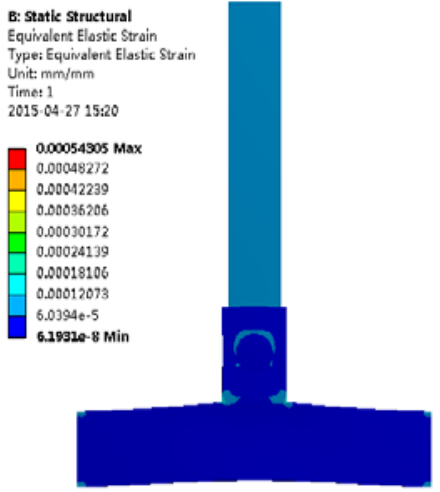

Strain nephogram

Figure 5. Analysis result

At last, the system distortion of the selected optimal plan is about $0.034 \mathrm{~mm}$ which satisfy the requires of stiffness of the electric vehicles frame; and the maximum stress of the system is 43.842Mpa which is much less than the admissible stress of the structure steel (250Mpa) and the admissible stress of the Aluminum alloy (280Mpa), so it can satisfy the requirements well for the electric vehicles. 


\section{References}

[1] BENEDYK J C. Light metals in automotive applications[J]. Light Metal Age,2000,10(1):34-35.

[2] Pedersen P. On Optimal Shapes in Materials and Structures[J]. Structure.Multidisc.Optim. 2000,9(2):169-182.

[3] Markus Pfestorf. Multimaterial light weight design for the body in white of the new BMW 7 series[C]. International Conference: Innovative Developments for Lightweight Vehicle Structures, Wolfsburg Germany, 2009:219-230

[4] Hongbing Fang,Mark F.Horstemeyer. Global response approximation with radial basis functions[J]. Engineering Optimization,2006,38:04,407-424

[5] Xintao Cui, Shuxin Wang, S. Jack Hu. A method for optimal design of automotive body assembly using multi-material construction [J]. Materials and Design, 2008, 29:381-387 